\title{
PPM BUM Desa Gosari Kecamatan Ujung Pangkah Kabupaten Gresik
}

\author{
Aminatuzzuhro', Andi Iswoyo², Yanuar Fauzuddin ${ }^{3}$, Hendrik Rizqiawan ${ }^{4}$ \\ ${ }^{1}$ Universitas Wijaya Putra \\ ${ }^{2}$ Universitas Wijaya Putra \\ ${ }^{3}$ Universitas Wijaya Putra \\ ${ }^{4}$ Universitas Wijaya Putra
}

aminatuzzuhro@uwp.ac.id, andi@uwp.ac.id, yanuarfauzuddin@uwp.ac.id, hendrikrizqiawan@uwp.ac.id

\begin{abstract}
Abstrak
Indonesia merupakan negara yang memiliki berbagai kekayaan sumber daya alam, baik itu lautan, sungai, hingga pegunungan, dan berbagai ragam kekayaan alam lainnya. Indonesia juga masyur dikenal sebagai negara dengan banyak aneka keanekaragaman budaya dan peninggalan bersejarah. Sumber daya alam, budaya dan peninggalan bersejarah yang berlimpah tersebut jika dikelola dengan benar dan tepat dapat memberikan keuntungan besar bagi negara, meningkatkan pendapatan daerah, dan tentunya dapat memberikan kesejahteraan bagi masyarakat sekitar. Salah satu pendayagunaannya adalah dengan menciptakan daerah tersebut menjadi tempat sarana destinasi wisata. Wisata Alam Gosari (WAGOS) merupakan salah satu unit usaha yang dikelola oleh BUM Desa Gosari Kecamatan Ujung Pangkah, Kabupaten Gresik. WAGOS sudah berdiri sejak 2017 dan dikunjungi sebanyak hingga ribuan pengunjung di tiap akhir pekan dan ratusan pengunjung di tiap hari kerja.

Selama beroperasional dalam 4 tahun ini, ada berapa permasalahan WAGOS yang teridentifikasi, antara lain pada bidang produksi yaitu pengelola dianggap belum maksimal dalam mengelola kebersihan lokasi wisata, hal tersebut tampak dari kurangnya bak sampah yang tersedia serta tidak adanya papan tanda (sign board) terkait himbauan untuk menjaga kebersihan yang ditujukan kepada pengunjung. Kemudian permasalahan pada manajemen usaha ialah pencatatan akuntansi masih semi-manual dan tidak jarang salah melakukan pencatatan. Pada pengelolaan SDM, pengelola WAGOS menyadari adanya kekurang-kompakan antar pekerja atau team work. Beberapa diantaranya kerap dijumpai kurang bersinergi dengan pekerja yang lain. Pelaksanaan kegiatan pendampingan ini antara lain: (1) Persiapan tim dan melakukan koordinasi dengan mitra (BUM Desa Gosari), (2) Penyusunan rencana (jadwal) kegiatan, (3) Pengadaan bak sampah dan papan tanda (sign board) terkait himbauan untuk menjaga kebersihan, beserta distribusi dan serah terimanya, (4) Pelatihan pencatatan akuntansi dengan memanfaatkan aplikasi yang tepat dan sesuai standar akuntansi, (5) Pelatihan team work, (6) Evaluasi pelaksanaan kegiatan.
\end{abstract}

Kata Kunci: BUM Desa, Wisata Alam, Gresik

\section{PENDAHULUAN}

Indonesia merupakan negara yang memiliki berbagai kekayaan sumber daya alam, baik itu lautan (62\% dari luas negara Indonesia), sungai (dengan garis pantai sepanjang $81.000 \mathrm{~km}$ ), hingga pegunungan, dan berbagai lainnya. Indonesia juga masyur dikenal sebagai negara dengan beraneka keanekaragaman budaya dan peninggalan bersejarah. Sumber daya alam, budaya dan peninggalan bersejarah yang berlimpah tersebut jika dikelola dengan benar dan tepat dapat memberikan keuntungan besar bagi negara, meningkatkan pendapatan daerah, dan tentunya dapat memberikan 
kesejahteraan bagi masyarakat sekitar. Salah satu pendayagunaannya adalah dengan menciptakan daerah tersebut menjadi tempat sarana destinasi wisata. Daerah-daerah yang dianugrahi sumber daya alam yang eksotis, kekayaan budaya dan penginggalan bersejarah diharapkan dapat memberikan kontribusi besar dalam memberikan sumber pendapatan. Apalagi dengan adanya otonomi daerah sebagaimana Undang-Undang Nomor 2 Tahun 2015, daerah (provinsi dan kabupaten/kota) memiliki hak, wewenang, dan kewajiban daerah otonom untuk mengatur dan mengurus sendiri Urusan Pemerintahan dan kepentingan masyarakat setempat dalam sistem Negara Kesatuan Republik Indonesia. Dalam Permendesa PDTT Nomor 4 Tahun 2015 juga menyebutkan Pemerintah Desa beserta masyarakat desa dapat mendirikan BUM (Badan Usaha Milik) Desa dengan beberapa pertimbangannya yaitu potensi usaha ekonomi dan sumber daya alam di desa.

Mitra merupakan BUM Desa Gosari yang memiliki usaha wisata alam dengan nama Wisata Alam Gosari (WAGOS) di Desa Gosari, Kecamatan Ujung Pangkah, Kabupaten Gresik. Keberadaan BUM Desa Gosari telah memiliki legalitas berupa Peraturan Desa, sesuai dengan yang tertuang pada Undang-Undang No. 6 Tahun 2014 Tentang Desa dan Peraturan Menteri Desa, Pembangunan Daerah Tertinggal dan Transmigrasi No. 4 Tahun 2015 tentang Pendirian, Pengelolaan dan Pembubaran BUM Desa. Usaha wisata alam yang dijalankan sudah berdiri sejak 2017 akhir atau beroperasional selama 4 tahun. BUM Desa Gosari dalam pengelolaan WAGOS memiliki tanah seluas 8 ha yang merupakan aset desa dan baru didayagunakan seluas 1,5 ha. Di area WAGOS juga memiliki nilai sejarah yang cukup tinggi. Salah satunya adalah keberadaan Prasasti Gua Butulan. Prasasti tersebut diduga sudah ada semenjak abad ke 14 atau tahun 1376 Masehi (Jonesuan, 2021:2). Pengelola WAGOS sebanyak 14 orang yang berawal sebagai Pokdarwis, dengan struktur organisasi sebagai unit usaha di bawah BUM Desa Gosari. Wahana yang dimiliki saat ini adalah Kolam Kecil Anak, Kolam Ikan, Taman Bunga, Permainan ATV, Permainan Mobil Aki dan Outbond. Wahana yang saat ini tidak aktif lagi adalah Outbond. Fasilitas yang disediakan yaitu lahan parkir, warung makan, cafe, gazebo, toilet dan mushola. WAGOS menyediakan "kereta kelinci" sebagai fasilitas penjemputan rombongan pengunjung yang menggunakan transportasi bis, karena dari jalan utama desa harus masuk melalui jalan sepanjang 400 meter yang hanya cukup dilalui 1 mobil. Harga tiket masuk yang diberikan Rp. 10.000/orang dewasa, Rp. 5.000/anak-anak, Rp. 10.000/ mobil dan Rp. 2.000/sepeda motor. Harga tiket ini merupakan harga yang baru diterapkan pada bulan Juli 2020 yang sebelumnya masih 50\% dibawahnya.

Tahun 2018, WAGOS mendapatkan jumlah pengunjung sebanyak 200 orang tiap akhir pekan dan tanpa pengunjung di hari kerja. Tahun 2019, mendapatkan 500 pengunjung tiap akhir pekan dan 50 pengunjung di tiap hari kerja. Tahun 2020 ini, mendapatkan hingga ribuan pengunjung di tiap akhir pekan dan ratusan pengunjung di tiap hari kerja. Meskipun terjadi tren peningkatan jumlah pengunjung dan mengalami perkembangan usaha, WAGOS sebagai unit usaha BUM Desa Gosari belum mampu memberikan kontribusi terhadap PADes (Pendapatan Asli Desa). Selama ini memang pengelola WAGOS memprioritaskan pada perbaikan dan pengembangan fasilitas usaha wisata dari pemanfaatan hasil laba usahanya. Terakhir, penambahan fasilitas yang telah dilakukan adalah pembangunan Cafe Bambu dan Penambahan Wahana Kolam Air. Selama beroperasional dalam 4 tahun ini, ada berapa permasalahan WAGOS yang teridentifikasi, antara lain pada bidang produksi yaitu pengelola dianggap belum maksimal dalam mengelola kebersihan lokasi wisata, hal tersebut tampak dari kurangnya bak sampah yang tersedia serta tidak adanya papan tanda (sign board) terkait himbauan untuk menjaga kebersihan yang ditujukan kepada pengunjung. Tentunya hal tersebut dapat mengakibatkan sampah yang berserakan, dan terlihat pada beberapa sudut area wisata khususnya area cafe bawah, masih ditemui sampah berceceran. Padahal cafe merupakan salah satu spot yang sering didatangi pengunjung wisata untuk melepas lelah, lapar dan dahaga. Kebersihan pada cafe perlu dijaga karena area yang bersih merupakan salah satu indikator bukti fisik pada aspek kualitas layanan yang dapat memuaskan pengunjung (Rizqiawan \& Prihantono, 2020). Kemudian permasalahan 
berikutnya yaitu pada manajemen usaha, dimana pencatatan akuntansi masih semi-manual dan tidak jarang salah melakukan pencatatan. Sejak beroperasional dari tahun 2017, pengelolaan pencatatan akuntansi baru diperhatikan pada pertengahan 2020, karena mereka baru memiliki SDM yang memiliki kompetensi bidang akuntansi dan itupun fresh graduate yang belum memiliki pengalaman kerja dibidangnya. Permasalahan berikutnya adalah pada pengelolaan SDM, pengelola WAGOS menyadari adanya kekurangkompakan antar pekerja atau team work. Beberapa diantaranya kerap dijumpai kurang bersinergi dengan pekerja yang lain. Berdasarkan analisis dan identifikasi tersebut, maka program pemberdayaan masyarakat ini dilaksanakan dengan tujuan antara lain: 1) Wisata Alam Gosari atau WAGOS memiliki papan tanda (sign board) terkait himbauan untuk menjaga kebersihan yang ditujukan kepada pengunjung dan tambahan bak sampah; 2) Pengelola WAGOS khususnya bagian bendahara, dapat melakukan pencatatan akuntansi dengan memanfaatkan aplikasi yang tepat dan sesuai standar akuntansi; 3) Para pekerja WAGOS bisa lebih kompak dan memiliki semangat team work yang baik dalam menjalankan tugas-tugas yang telah ditentukan.

\section{METODE}

Sebelum melaksanakan program pemberdayaan masyarakat ini, tim yang terdiri dari 4 Dosen dan 2 Mahasiswa Universitas Wijaya Putra ini terlebih dahulu melakukan koordinasi (sosialisasi program) serta persiapannya dengan melibatkan pengurus BUM Desa Gosari dan tentunya dengan pengelola Wisata Alam Gosari (WAGOS). Program disepakati dilaksanakan pada hari kerja, dikarenakan pada hari sabtu dan minggu (weekend), pengelola WAGOS fokus melayani pengunjung yang dating. Sebagaimana tempat wisata yang lain, pada hari sabtu dan minggu merupakan waktu dimana banyak orang berkunjung untuk berwisata.

Adapun program yang telah dijalankan pada program pemberdayaan masyarakat ini adalah 1) Pengadaan bak sampah dan papan tanda (sign board) terkait himbauan untuk menjaga kebersihan, beserta distribusi dan serah terimanya; (2) Pelatihan pencatatan akuntansi dengan memanfaatkan aplikasi yang tepat dan sesuai standar akuntansi. Pada program pelatihan ini melibatkan bendahara WAGOS; (3) Pelatihan team work dengan menggunakan pendekatan permainan tim.

\section{HASIL DAN PEMBAHASAN}

\section{1 Pelaksanaan Program pada Bidang Produksi - Pengadaan Perlengkapan Kebersihan Lingkungan}

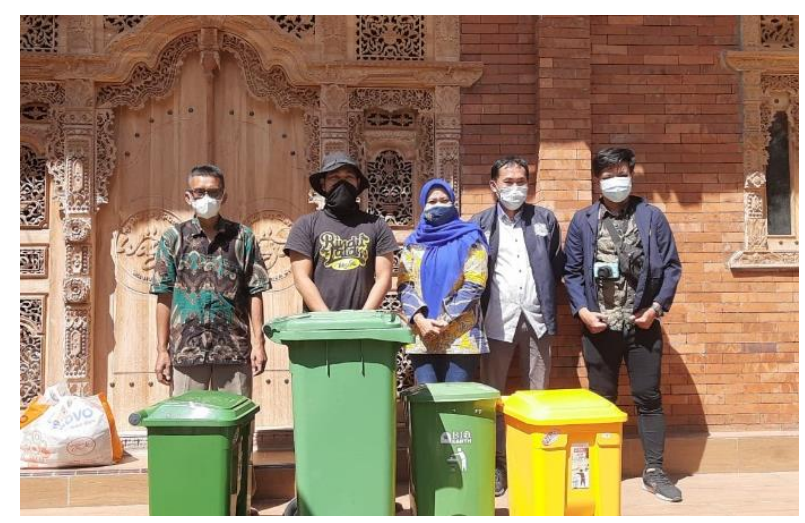

Gambar 1. Penyerahan Bak Sampah kepada

Pengurus BUM Desa Gosari Bapak Mujib Ridlwan dan Pengelola WAGOS Bapak Misbahuddawam

Tidak dipungkiri, apresiasi patut diberikan kepada pengurus BUM Desa, pengelola Wisata Alam Gosari (WAGOS) dan pejabat desa Gosari. Dimana mampu mendirikan dan menjalankan usaha berupa wisata alam yang dapat menghasilkan keuntungan, walaupun selama ini laba yang didapatkan digunakan untuk biaya operasional dan lebih diprioritaskan pemanfaatannya pada perbaikan dan pengembangan fasilitas usaha. Namun dalam proses perbaikan dan pengembangan usaha, masih ada beberapa hal yang perlu dievaluasi. Salah satunya adalah keseriusan pengelola dalam dalam mengelola kebersihan lokasi wisata. Kebersihan dapat dijadikan salah satu indikator yang penting pada aspek kualitas objek wisata. (Lese et al., 2020). Semakin berkualitasnya area wisata, tentunya dapat berimbas pada minat orang untuk berkunjung. Dengan kurangnya bak sampah yang 
tersedia serta tidak adanya papan tanda (sign board) terkait himbauan untuk menjaga kebersihan yang ditujukan kepada pengunjung, tentunya hal tersebut dapat mengakibatkan sampah yang berserakan, dan terlihat pada beberapa sudut area wisata WAGOS (khususnya area cafe bawah) masih ditemui sampah berceceran. Oleh karena itu, tim melakukan pengadaan bak sampah sebanyak 4 unit dengan masing-masing berukuran $120 \mathrm{lt}, 50 \mathrm{lt}$ dan $40 \mathrm{lt}$. Selain itu, tim juga menyerahkan beberapa papan tanda (sign board). Keberadaan bak (tong) sampah dan papan tanda (peringatan) yang memadai dapat menjadi faktor pendorong agar pengunjung wisata membuang sampah pada tempatnya (Elsa \& Helvi, 2019).

\section{2 Pelaksanaan Program pada Bidang Manajemen Usaha - Pelatihan Pencatatan Akuntansi}

Pelatihan pencatatan akuntansi dengan memanfaatkan aplikasi yang tepat dan sesuai standar akuntansi diberikan kepada bendahara WAGOS yang bernama Bapak Mifatchul. Dia ditempatkan menjadi bendahara pada pertengahan tahun 2020, karena dianggap memiliki kompetensi bidang akuntansi dan termasuk baru rampung menyelesaikan pendidikannya atau fresh graduate. Pelatihan menggunakan media laptop dan software excel (Ms. Ofice). Adapun materi pelatihan meliputi kaidah pencatatan dan penyusunan laporan keuangan, penyusunan laporan laba rugi dan pentingnya akuntabilitas dan transparansi laporan keuangan. Laporan keuangan sendiri dianggap aspek yang vital dalam pengelolaan usaha, hal tersebut menyediakan informasi terkait kondisi (posisi) keuangan, kinerja, serta perubahan posisi keuangan suatu organisasi usaha yang dapat digunakan dalam pengambilan keputusan usaha atau ekonomi (Tambunan, 2020). Tentunya dengan peningkatan kemampuan atau kompetensi Bapak Mifatchul (selaku bendahara WAGOS) dalam pencatatan akuntansi dan pengelolaan keuangan, dapat berimbas pada efektivitas penggunaan dana untuk perbaikan dan pengembangan fasilitas usaha wisata. Kemampuan instansi dalam mengelola keuangan merupakan bagian dari kinerja keuangan yang menunjukan bagaimana kondisi keuangan instansi tersebut, dalam rangka mengukur efektivitas dan efisiensi penggunaan dana atau anggarannya (Aminatuzzuhro \& Sodikin, 2017). Selama berlangsungnya pelatihan, Bapak Miftachul sangat antusias dan kooperatif. Beberapa pertanyaan dilontarkan jika ada yang kurang dipahami.

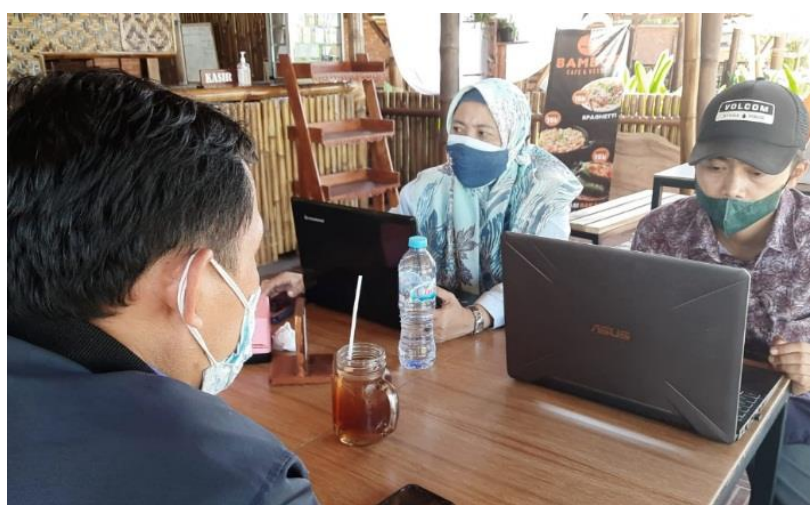

Gambar 2. Pelatihan Pencatatan Akuntansi dengan Peserta Bendahara WAGOS

\subsection{Pelaksanaan Program pada Bidang Manajemen Usaha - Pelatihan Team Work Hampir keseluruhan pekerja yang} dikaryakan untuk membantu berjalannya operasional Wisata alam Gosari (WAGOS) adalah berasal dari masyarakat Desa Gosari. Beberapa diantaranya merupakan anggota karang taruna setempat dengan rata-rata usia yang relaif masih muda. Beberapa diantaranya kerap dijumpai kurang bersinergi dengan pekerja yang lain. Pengelola WAGOS menyadari adanya kekurang-kompakan diantara mereka, sehingga merasa perlu ada pelatihan yang dapat membangun kekompakan bersama atau team work. Adapun pelatihan menggunakan pendekatan permainan yang lazim ada pada kegiatan out bound. Antara lain "All Standing Up" dimana permainan diawali dengan sepasang peserta pelatihan (berdua) membentuk sebuah tim dan duduk berhadapan. Kemudian masing-masing ujung kaki saling dikaitkan dan tangan saling berpegangan. Lalu mereka diminta untuk dapat berdiri bersama secara serempak atau berbarengan. Dalam pelaksanaannya pada saat itu mayoritas peserta berhasil melakukannya, sehingga 
tingkat kesulitan ditambah dengan menambahkan jumlah peserta tiap tim menjadi $3,4,5$ hingga seluruh seluruh peserta yang terdiri dari 21 orang dibagi menjadi 2 tim dan diminta melakukan "All Standing Up" berbarengan. Kemudian tantangan diubah, diawali dari 2 orang lagi seperti sebelumnya membentuk sebuah tim, namun duduk saling membelakangi. Peserta diminta berdiri tapi tidak dengan menggunakan kaki dan tangan yang terkait melainkan dengan bantuan punggung teman setimnya. Begitu seterusnya hingga keseluruhan peserta dibagi menjadi 2 tim besar. Pada permainan ini, Kepala Desa Gosari Bapak Fathul Ulum ikut hadir dan bahkan berkenan terlibat pada permainan tersebut.

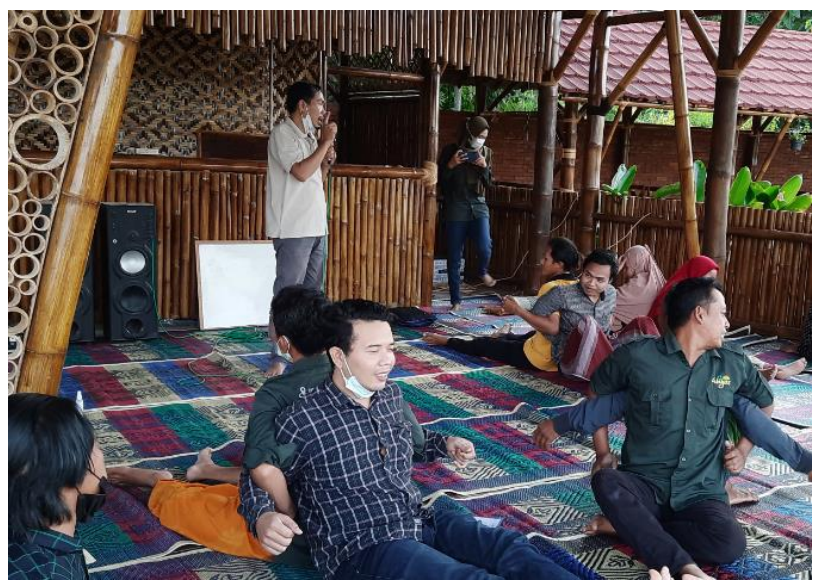

Gambar 3. Permainan "All Standing Up"

Permainan berikutnya yang digunakan pada pelatihan team work adalah "Bola Bergulir". "Bola Bergulir" merupakan bentuk permainan yang cukup efektif untuk membangun kekompakan, komunikasi, ketelitian, kesabaran hingga kebersamaan dalam sebuah tim. Permainan ini dimainkan pada pelatihan dengan melibatkan sebanyak 7 hingga 8 peserta dalam 1 tim. Alat yang digunakan antara lain bola tenis meja, ruas potongan bambu sepanjang sekitar 1 meter dan peluit. Permainan "Bola Bergulir" dimulai dengan setiap peserta membawa 1 ruas potongan bambu kemudian diminta berdiri berjajar, lalu bola tenis meja digulirkan dari ujung hingga ke ujung tanpa jatuh. Setiap tim dituntut untuk dapat menyelesaikan guliran bola tenis meja dari ujung ke ujung tanpa jatuh dan berkompetisi tim mana yang lebih dahulu berhasil. Pada pelaksanaannya para peserta kesulitan memainkannya, dari 3 tim hanya 1 tim yang berhasil, itupun hasil dari percobaan yang berulang-ulang. Para peserta dituntut sabar, saling bekerja sama dan saling memahami antar sesama agar bola tenis meja dapat bergulir sesuai harapan. Dalam sela-sela permainan, para peserta diberikan waktu untuk diskusi agar dapat saling mengevaluasi terkait permainan mereka, baik dari sisi kerja sama dan perilaku individu. "All Standing Up" dan "Bola Bergulir" merupakan permainan yang lazim dilakukan ketika melakukan outbound, walaupun pada pelatihan ini berlokasi di sebuah ruangan, namun ruangan tersebut cukup terbuka (tidak ada dinding dan pintu yang membatasi). Permainan yang kompetitif merupakan salah satu indikator pada outbond training (As'adi, 2009). Pelatihan outbond sendiri memiliki pengaruh yang cukup signifikan pada team work atau kerja sama tim (Umar, 2011). Selain itu outubond training dapat meningkatkan motivasi dan kinerja pekerja atau karyawan (Anisa \& Susilo, 2018).

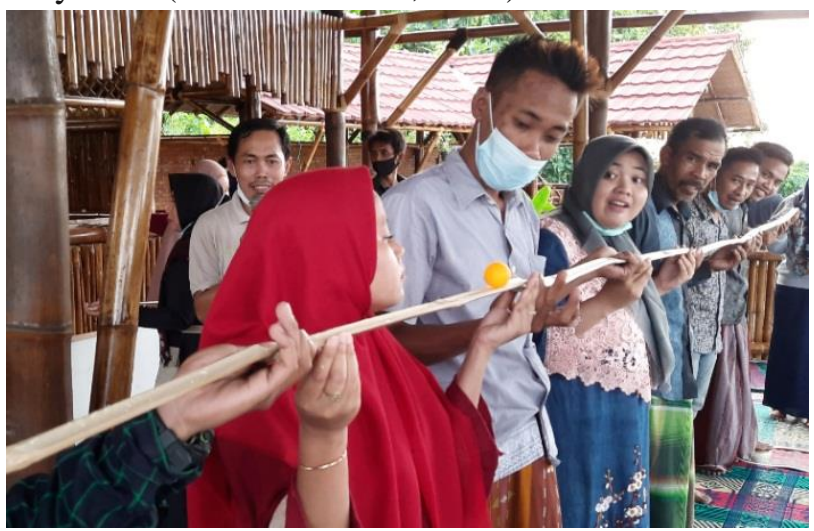

Gambar 4. Permainan "Bola Bergulir"

\section{KESIMPULAN}

Kegiatan pemberdayaan masyarakat ini dilaksanakan berfokus pada 3 pelaksanaan program yaitu 1) Pelaksanaan program pada bidang produksi - pengadaan perlengkapan kebersihan lingkungan; 2) Pelaksanaan program pada bidang manajemen 
usaha - pelatihan pencatatan akuntansi; dan 3) Pelaksanaan program pada bidang manajemen usaha - pelatihan team work. Keseluruhan pelaksanaan program berjalan sesuai rencana dan harapan. Mitra yang terdiri dari pengurus BUM Desa Gosari, pengelola dan pekerja WAGOS mengikuti program dengan baik. Mitra mempersilahkan dalam pelaksanaan program pemberdayaan masyarakat ini menggunakan area wisata. Dengan adanya pengadaan papan tanda (sign board) terkait himbauan untuk menjaga kebersihan yang ditujukan kepada pengunjung dan tambahan bak sampah (sebanyak 4 unit) diharapkan kebersihan lingkungan Wisata Alam Gosari (WAGOS) lebih terjaga, sehingga tidak ada lagi sampah yang berserakan yang terlihat pada beberapa sudut area wisata (khususnya area cafe bawah). Pelatihan pencatatan akuntansi (dilaksanakan dengan materi yang meliputi kaidah pencatatan dan penyusunan laporan keuangan, penyusunan laporan laba rugi dan pentingnya akuntabilitas dan transparansi laporan keuangan) diharapkan dapat memberikan manfaat pada mitra khususnya pada bendahara WAGOS agar pencatatan akuntansi kedepan dapat dijalankan dengan baik. Pelatihan team work yang menggunakan media permainan "All Standing Up" dan "Bola Bergulir" melibatkan 21 peserta yang merupakan pekerja dan pengelola WAGOS, bahkan pada salah satu permainan, Bapak Fathul Ulum selaku Kepala Desa Gosari berkenan ikut serta. Pelatihan ini dapat menjadi momentum dalam rangka meningkatkan kekompakan dan kerja sama sesama pekerja di Wisata Alam Gosari (WAGOS). Selama pelatihan team work para peserta mengikuti dengan penuh semangat, bahkan dalam sesi diskusi di sela-sela permainan, beberapa peserta memberanikan diri menyampaikan pendapat mereka agar tim bisa lebih kompak dan solid.

\section{UCAPAN TERIMAKASIH}

Ucapan terimakasih kami sampaikan kepada kepada Bapak Dr. Budi Endarto, SH.,
M.Hum (Rektor Universitas Wijaya Putra), LPPM Universitas Wijaya Putra, Ibu Dr. Soenarmi, SE., MM. (Dekan Fakultas Ekonomi dan Bisnis), Bapak Fathul Ulum (Kepala Desa Gosari), Bapak Mujib Ridlwan (Pengurus BUM Desa Gosari), Bapak Misbahuddawam (Pengelola WAGOS) dan semua pihak lain yang tidak dapat disebutkan satu persatu.

\section{REFERENSI}

Aminatuzzuhro, A. \& Sodikin, S. (2017). Peranan Penilaian Performance Good Public Governance melalui Sistem Pengendalian Manajemen di Rumah Sakit Umum daerah di Surabaya Barat. E-Jurnal Kewirausahan, 3(1): 4049. E-ISSN 2339-1804.

Anisa, R.F. \& Susilo, H. (2018). Pengaruh Outbound Training Terhadap Kinerja Karyawan Melalui Motivasi sebagai Variabel Intervening (Studi pada Kantor Pusat d'Besto, PT Evalinda Berkah Mandiri Jakarta). Jurnal Administrasi Bisnis (JAB), 60(1): 204-210.

As'adi, Muhammad. (2009). The Power of Outbound Training. Yogyakarta: Ihdina.

Elsa, N. \& Helvi, A. (2019). Peran Pokdarwis dalam Pembinaan Perilaku Buang Sampah pada Wisatawan (Studi Kasus Di Pantai Goa Cemara, Kabupaten Bantul, D.I.Y). Bachelor thesis, Universitas Ahmad Dahlan. http://eprints.uad.ac.id/id/eprint/15221.

Jonesuan, Fatee. (2021). Mitologi - Sejarah Prasasti Gosari 1376 M. Raja Sanjaya - Sanrama Samadaya di Gua Butulan. Gresik: Yayasan Masyarakat Pecinta Sejarah \& Budaya Gresik.

Lese, F.W., Fanggidae, R.E. \& Fanggidae, A.H.J. (2020). Pengaruh Kualitas Objek Wisata Terhadap Minat Berkunjung Wisatawan (Studi Pada Wisatawan Di Pantai Warna-Warni Oesapa, Kupang). Glory: Jurnal Ekonomi dan Ilmu Sosial, 1(1):25-38.

Peraturan Menteri Desa, Pembangunan Daerah Tertinggal dan Transmigrasi Nomor 4 Tahun 2015, tentang Pendirian, Pengurusan dan Pengelolaan dan Pembubaran Badan Usaha Milik 
Desa.

Rizqiawan, H., \& Prihantono, D. (2020). Analisis Kualitas Layanan terhadap Kepuasan Pelanggan: Perbandingan pada Modern Retail Minimarket dengan Toko Kelontong di Kota Surabaya. Jurnal Manajerial Bisnis, 3(3), 201-210. https://doi.org/10.37504/mb.v3i3.256.

Tambunan, L.T. (2020). Fungsi Sistem Informasi Akuntansi dalam Meningkatkan Efisiensi dan Efektivitas Pelaporan Keuangan pada Badan Usaha Milik Daerah Provinsi Sumatera Utara. Junal Ilmiah Simantek, 4(1):81-95.

Umar, T. (1). Pengaruh Outbond Training Terhadap Peningkatan Rasa Percaya Diri Kepemimpinan dan Kerjasama Tim. Jurnal Ilmiah Spirit, 11(3). https://doi.org/10.36728/jis.v11i3.39. Undang-Undang Republik Indonesia Nomor 6 Tahun 2014 tentang Desa. 